\title{
Application of Response Surface Methodology for Optimization of Fluoride Removal Mechanism by Newely Developed Biomaterial
}

\author{
Ria Bhaumik, Naba Kumar Mondal ${ }^{*}$, Soumya Chattoraj, Jayanta Kumar Datta \\ Department of Environmental Science, The University of Burdwan, Burdwan, India \\ Email: ${ }^{*}$ nkmenvbu@gmail.com
}

Received May 17, 2013; revised June 17, 2013; accepted July 15, 2013

Copyright (C) 2013 Ria Bhaumik et al. This is an open access article distributed under the Creative Commons Attribution License, which permits unrestricted use, distribution, and reproduction in any medium, provided the original work is properly cited.

\begin{abstract}
The adsorption capacities of new biomaterials derived from lemon leaf (Citrus sp.) toward fluoride ions have been explored by varying different physicochemical parameters such as $\mathrm{pH}$, initial concentration, adsorbent dose, contact time, stirring rate and temperature. The entire study was done through batch process. Maximum fluoride adsorption of $96.9 \%$ - 98.8\% was achieved with an initial concentration of $10 \mathrm{mg} / \mathrm{L}$. Langmuir isotherm model well expressed fluoride adsorption onto LLD-1, LLD-2 and LLD-3. According to correlation coefficient, the fluoride adsorption onto these 3 adsorbents was correlated well with pseudo-second-order kinetic model. From thermodynamic study, the spontaneous nature and feasibility of the adsorption process with negative enthalpy $\left(\Delta \mathrm{H}^{0}\right)$ value also supported the exothermic nature were shown. The rate of fluoride adsorption was mathematically described as a function of experimental parameters and was modeled through Box-Behnken (Response surface methodology). The results showed that the responses of fluoride adsorption were significantly affected by the quadratic term of $\mathrm{pH}$, initial concentration, contact time and temperature and the statistical analysis was performed by ANOVA which indicated good correlation of experimental parameters.
\end{abstract}

Keywords: Lemon Leaf; Fluoride; Adsorption; Langmuir Isotherm; Pseudo-Second-Order Kinetic Model; Thermodynamic Study; Response Surface Methodology

\section{Introduction}

Fluorine is one of the strong electronegative elements and its gaseous form is tremendous powerful oxidizing agent. It exists in underground water as fluoride ion $\left(\mathrm{F}^{-}\right)$. However, natural abundance of fluorine ranges from $0.06 \%$ to $0.09 \%$ by weight in the earth crust [1].

Fluoride is mainly toxic to the human body when it exceeds the threshold limit of $1.5 \mathrm{mg} / \mathrm{L}$ [2]. The excess intake of fluoride may cause fluorosis (dental and skeletal), neurological damage [3] decreasing growth and intelligence [4]. There is a tremendous demand for for removal of fluoride from drinking water. In recent years, various plant materials like coconut shell [4], bone char, [5] tamarind seed, neem and kikar leaves [6], Barmuda grass [7] neem charcoal [8], Moringa oleifera seed [9] have also been used as adsorbents for defluoridation. There is a gap in knowledge about the carbonized and chemically treated forms. But classical batch adsorption technique is unable to provide fine optimization. To

*Corresponding author. overcome such a problem by taking the help of computerize optimization process called Response Surface Methodology (RSM), in this study lemon leaf was chosen for fluoride adsorption as dried powder (LLD-1), carbonized form (LLD-2) and chemically treated (LLD-3) together to establish new adsorbents for defluoridation. Due to carbonization high specific surface area occurred in the adsorbent and due to chemical treatment, more binding sites appear which are responsible for more fluoride adsorption than naturally occurring materials.

It is well known that consumption of lemon leaf is one of the most common fruit grown mainly in all tropical countries, including India. In fresh samples, high levels of calcium occur in the vacuoles and especially the inner tangenital walls of epidermal and sub-epidermal cells near the gap of the abscission zone. Calcium containing crystals (calcium oxalate) is also abundant in vacuoles of the cortex parenchyma and leaf blade sides [10]. In 2004, Storey and Leig explained citrus leaves accumulate large amounts of calcium in palisade, spongy mesophyll and crystal containing idioblast cells. 
RSM (Response Surface Methodology), an empirical modeling technique [11], is used to estimate the relationship between a set of controllable experimental factors and observed results. RSM consists of 3 major steps: performing statistically designed experiments, estimating the coefficients in a mathematical model and predicting the response and checking the adequacy of the model. RSM can avoid the limitations of conventional methods and is commonly used in many fields [12]. In this study a class of three level complete factorial designs (BoxBehnken model) was used to determine the show and the effects of major operating variables on fluoride adsorption and to find the combination of variables resulting in maximum fluoride adsorption efficiency. This design was applied using Design Expert Software 7.0 with six variables at 3 levels. Four different parameters such as initial fluoride concentration, $\mathrm{pH}$, contact time and temperature were selected as the critical variables. A total of 17 experiments have been employed in this work to estimate the effects of the six main independent variables on fluoride adsorption efficiency.

This present study searches new technology involving the removal of fluoride from contaminated water due to adsorption based on binding capacities of calcium (with fluoride) presented in lemon leaf. The major advantages of this study fluoride adsorption by lemon leaf powder, activated carbon and chemically treated lemon leaf powder also include low cost, high efficiency and minimizetion of fluoride contaminated water.

\section{Adsorbents Development}

The adsorbent material named as lemon leaves were obtained from University farm and were washed with double distilled water in the laboratory. Then the leaves were dried at $50^{\circ} \mathrm{C}$ for $24 \mathrm{~h}$. One-third leaves were cut and grinded well by using mortar and pestle and then sieved to obtain the desired size fractions $(250 \mu \mathrm{m})$ and used as adsorbent LLD-1. Another 1/3 rd dried leaves are activated with $1 \% \mathrm{HCHO}$ solution and then again dried in oven maintained temperature range of $120^{\circ} \mathrm{C}-140^{\circ} \mathrm{C}$ for a period of $12 \mathrm{hrs}$. After that the ash material were ground and sieved [6] and used as adsorbent LLD-2. And the remaining part of leaves were treated with $\mathrm{Ca}^{+2}$ solution extracted from eggshell (LLD-3) [13] and used as adsorbent.

\section{Fluoride Adsorption Experiments}

The defluoridation studies were conducted for the optimization of various experimental conditions like $\mathrm{pH}$, initial concentration, adsorbent dose, contact time, stirring rate and temperature through batch process. The adsorption isotherm, kinetics and thermodynamic study were also done in this study. All the experiments were carried out at room temperature. Fluoride ion was measured with a specific ion-selective electrode (Orion ion selective) by use of TISAB II solution to maintain $\mathrm{pH} 5$ 5.5 .

The amount of fluoride adsorbed per unit adsorbent (mg fluoride/g adsorbent) was calculated according to a mass balance on the fluoride concentration using Equation (1):

$$
q_{e}=\frac{\left(C_{i}-C_{e}\right) x V}{m}
$$

The percent removal (\%) of fluoride was calculated using the following equation

$$
\operatorname{Removal}(\%)=\frac{\left(C_{i}-C_{e}\right)}{C_{e}} x 100
$$

\section{Results and Discussions}

\subsection{Characterization of the Adsorbents}

Physico-chemical characterizations of the adsorbents were shown in Table 1 and these characterizations were done by using standard methods.

From Table 1 comparing the important characteristics of LLD-1, LLD-2 and LLD-3, the carbon content of LLD-2 was higher than others due to increasing in the ash content.

Table 1 shows that LLD-3 and LLD-2 have the higher surface area and total pore volume than LLD-1 indicating the roughness of pore walls and increasing of additional active sites. Then more active sites are responsible for adsorption of fluoride ions onto the surface of the LLD-3 and LLD-2 than LLD-1.

Scanning electron microscopy (SEM) (Figure 1) helps to explain the surface structure of the powder consisting of the fine particles of irregular shape and size on external surface. Figure 1(c) shows SEM images of LLD-3 having particle size of $250 \mu \mathrm{m}$, where some deposits of calcium were observed only in the sample by modification of lemon leaf pure dust (LLD-1) (Figure 1).

Table 1. Physico-chemical Characteristics of LLD-1, LLD-2, LLD-3.

\begin{tabular}{cccc}
\hline Physical characteristics & LLD-1 & LLD-2 & LLD-3 \\
\hline $\mathrm{pH}$ & 6.2 & 6.7 & 8.5 \\
EC (mho/cm) & 1.5 & 1.6 & 1.7 \\
Bulk density $\left(\mathrm{g} / \mathrm{cm}^{3}\right)$ & 0.86 & 0.62 & 0.84 \\
Solubility in water (\%) & 0.5 & 0.7 & 0.8 \\
Solubility in acid (\%) & 0.6 & 0.75 & 0.89 \\
Moisture content (\%) & 4.2 & 4.6 & 4.9 \\
Ash content & - & 6.12 & - \\
BET Surface area & 285.6 & 824.3 & 804.5 \\
\hline
\end{tabular}




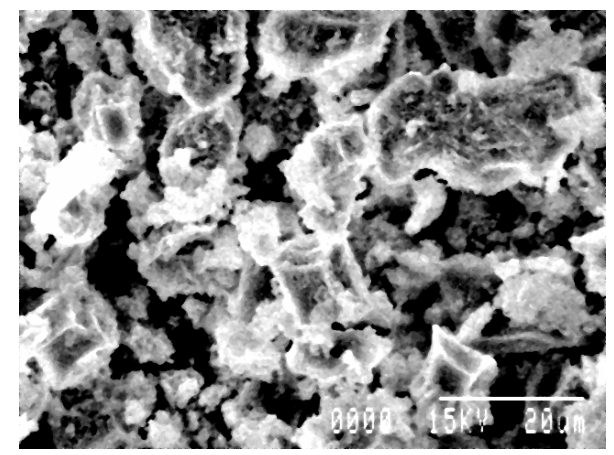

(a)

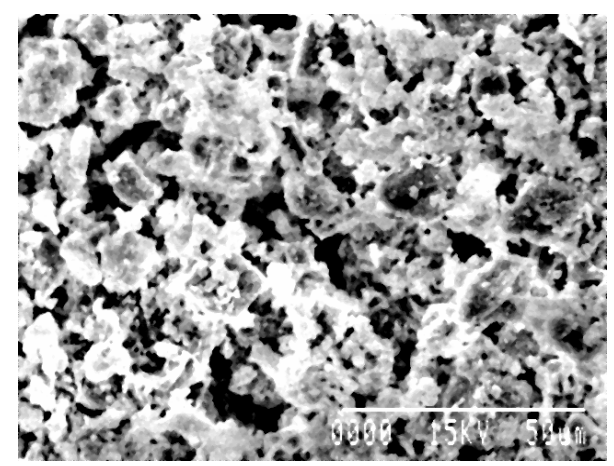

(b)

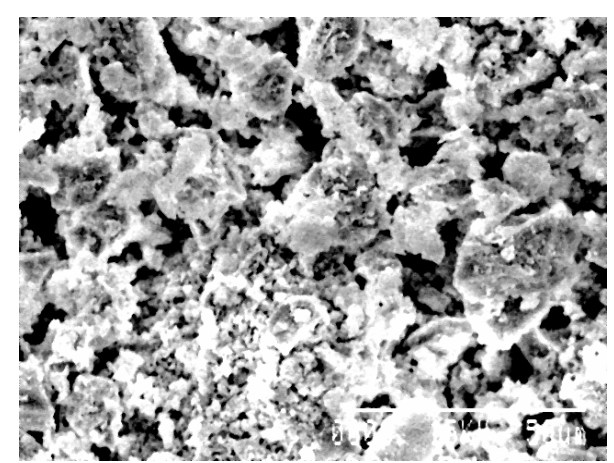

(c)

Figure 1. Scanning Electron Microscopy (SEM) images of LLD-1 (a), LLD-2 (b), LLD-3 (c).

FTIR measurements (Figure 2) of LLD-1, LLD-2 and LLD-3 showed the presence of peaks $589-607 \mathrm{~cm}^{-1}$ are due to $\mathrm{P}-\mathrm{O}$ bending vibration, $882-1098 \mathrm{~cm}^{-1}$ are due to $\mathrm{P}-\mathrm{O}$ stretching vibration. The inferred peaks at 2918 $3628 \mathrm{~cm}^{-1}$ are due to adsorption water. An adsorption bands are shown at $691-696 \mathrm{~cm}^{-1}$ and at $3571-3694$ $\mathrm{cm}^{-1}$ which are attributed to the $\mathrm{OH}$ groups.

Zero point charge $\left(\mathrm{pH}_{\mathrm{ZPC}}\right)$ of 3 adsorbents (LLD-1, LLD-2 and LLD-3) was measured by the solid addition method [14]. Changes in final $\mathrm{pH}$ from initial $\mathrm{pH}$ indicate the adsorptive process through dissociation of functional groups as the active sites on the surface of adsorbents. Figure 3 shows the point of zero charge of LLD-1, LLD-2 and LLD-3 7.0, 6.5 and 6.2 respectively. At low $\mathrm{pH}$, the surface of the adsorbent is positive and reaction predominates and at higher $\mathrm{pH}$ the surface of adsorbent is negative. Here, the $\mathrm{pH}$ of the fluoride solution becomes lower than point charge, the association of fluoride ions with the adsorbent surface easily takes place and this study the surface of LLD-3 is more effective than LLD-2 and LLD-1.

\subsection{Effect of $\mathrm{pH}$}

The $\mathrm{pH}$ of the fluoride solution varied from 2 to 10 and the $\mathrm{pH}$ was adjusted by adding $0.1(\mathrm{~N}) \mathrm{NaOH}$ and $0.1(\mathrm{~N})$ $\mathrm{HNO}_{3}$ soultion. Figures 4(a) and (b) show that both adsorption and fluoride uptake capacity are maximum at $\mathrm{pH}$ 6.0. Here, it is also shown that fluoride ions are more attached to the surface of LLD-3 due to chemically treated with $\mathrm{Ca}^{+2}$ solution (extracted from eggshell) at $\mathrm{pH}$ lower than $\mathrm{pH}$ zpc. $\mathrm{pH}$ played a vital role in fluoride adsorption onto biosorbent [15]. However, many researchers $[16,17]$ reported that biosorption of fluoride depends on the functional groups on the adsorbent and their ionic states. There are several studies concluded that biomass based biosorbent have several functional groups (such as amines, carbaryl, thiol, sulfhydryl, alcohol, phenol and phosphate groups) $[18,19]$. Study results reveled that highest fluoride adsorption occur at acidic $\mathrm{pH}(6.0)$ for all adsorbents. These sorption characteristics could be attributed to the ionic sorption with cationic $\left(\mathrm{H}^{+}\right)$adsorbent surface [17]. Under acidic condition the surface of the adsorbent transformed to a positively charged which facilitated the sorption of fluoride ion through anion exchange [18]. However, the percentage of fluoride removal inhibited at higher $\mathrm{pH}$, this might be attributed to the increase of hydroxyl ions leading to formation of aqua complexes.

\subsection{Effect of Initial Concentration and Adsorption Isotherm Models}

In the batch adsorption study after selection of $\mathrm{pH}$ the initial concentration $(1.5,3.0,5.0,10.0,15.0 \mathrm{mg} / \mathrm{L})$ is varied. Adsorption of fluoride (Figures 5(a) and (b)) increases up to initial concentration $10.0 \mathrm{mg} / \mathrm{L}$ (for all the three adsorbents) whereas at higher concentration adsorption is decreased. Lower concentration causes more interaction of fluoride ions with the binding sites and at higher concentration increase in the number of ions are responsible for competition in availability of binding sites in the adsorbent surface [20].

Moreover as the total available adsorption sites were limited, they became saturated at a higher concentration [14]. Similar trend has been reported for fluoride removal by using neem charcoal and eggshell dust $[21,22]$. The results of Figure 5 demonstrate that the amount of adsorbed fluoride increased with the increase of initial fluoride concentrations. The increase of fluoride 


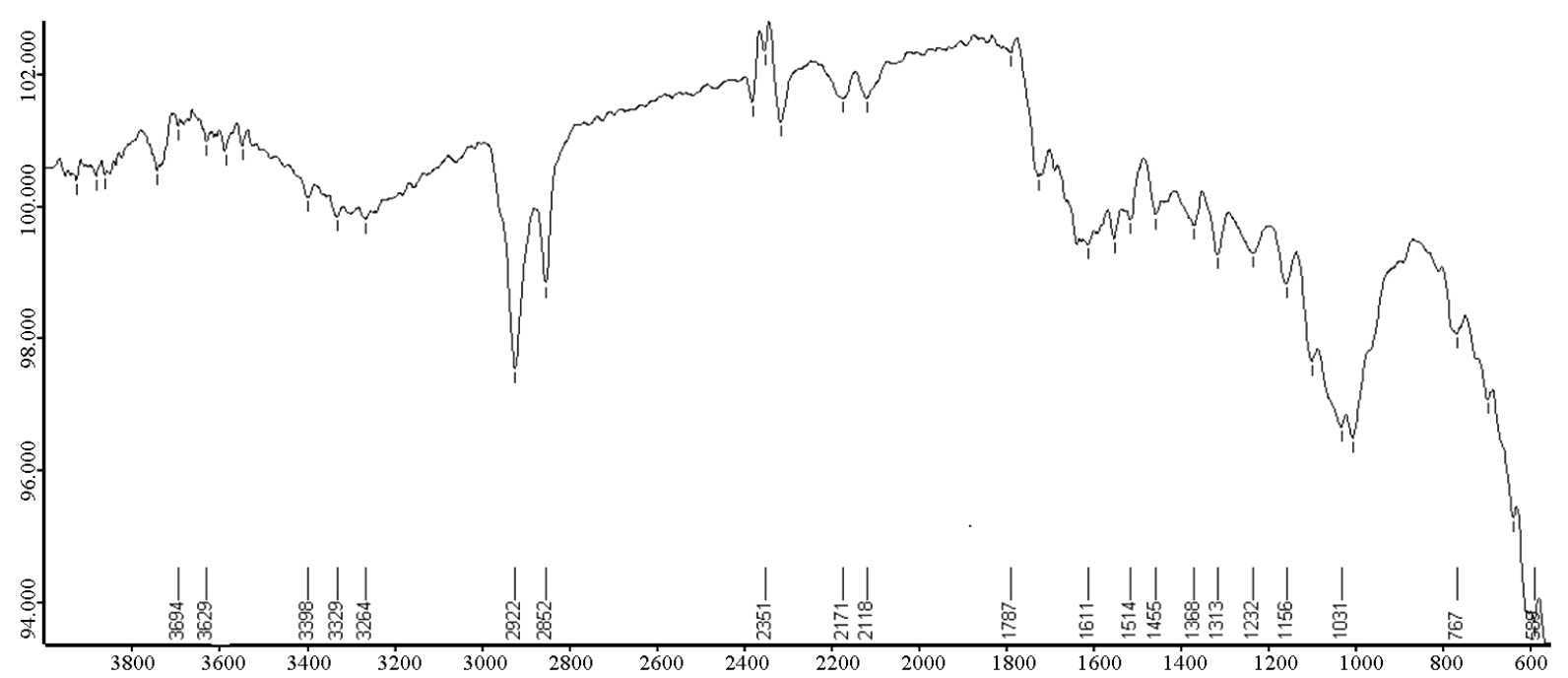

(a)

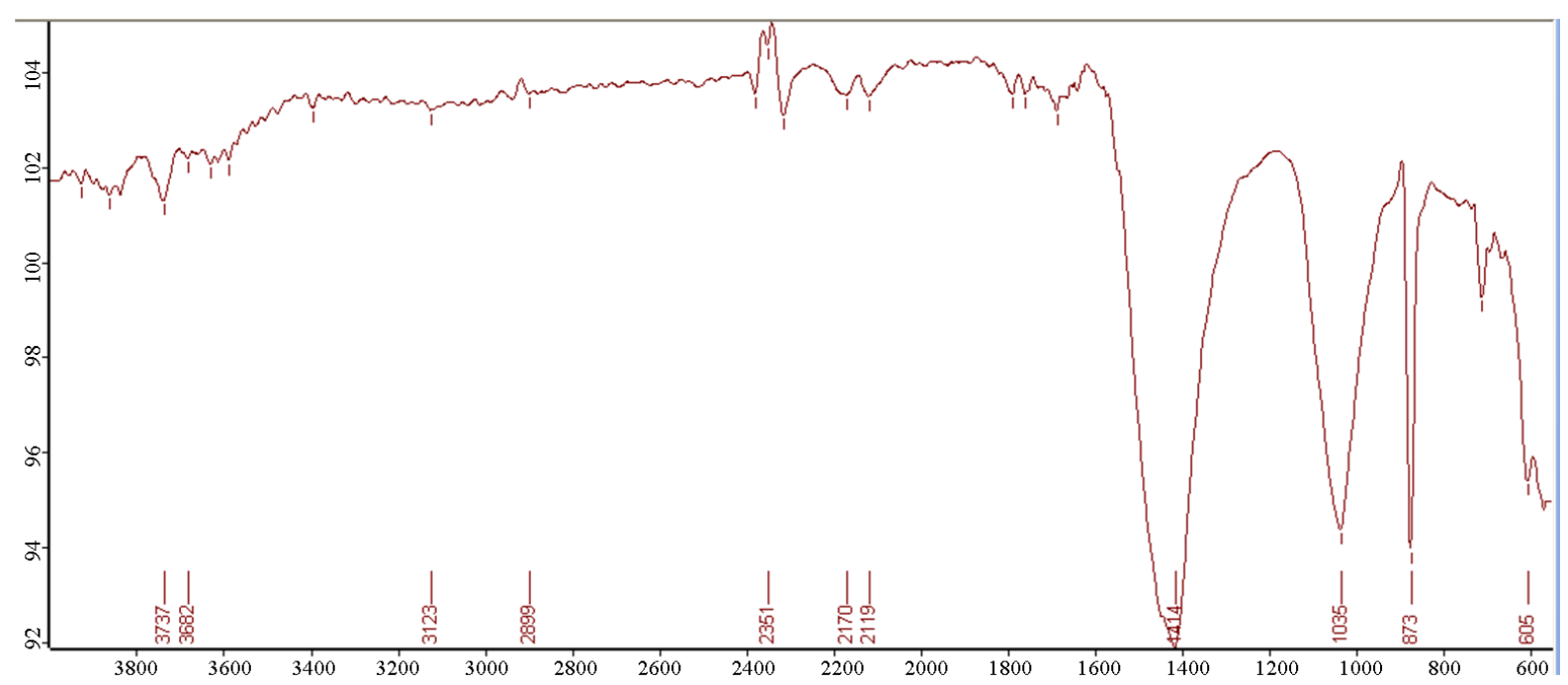

(b)

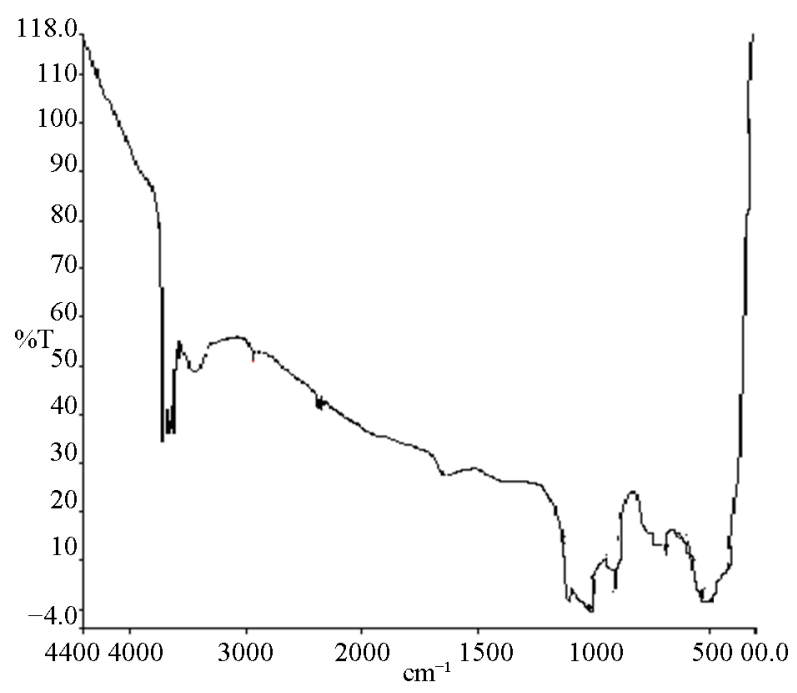

(c)

Figure 2. FTIR sprectrum of a) LLD-1, b) LLD-2 and c) LLD-3 before fluoride adsorpiton. 


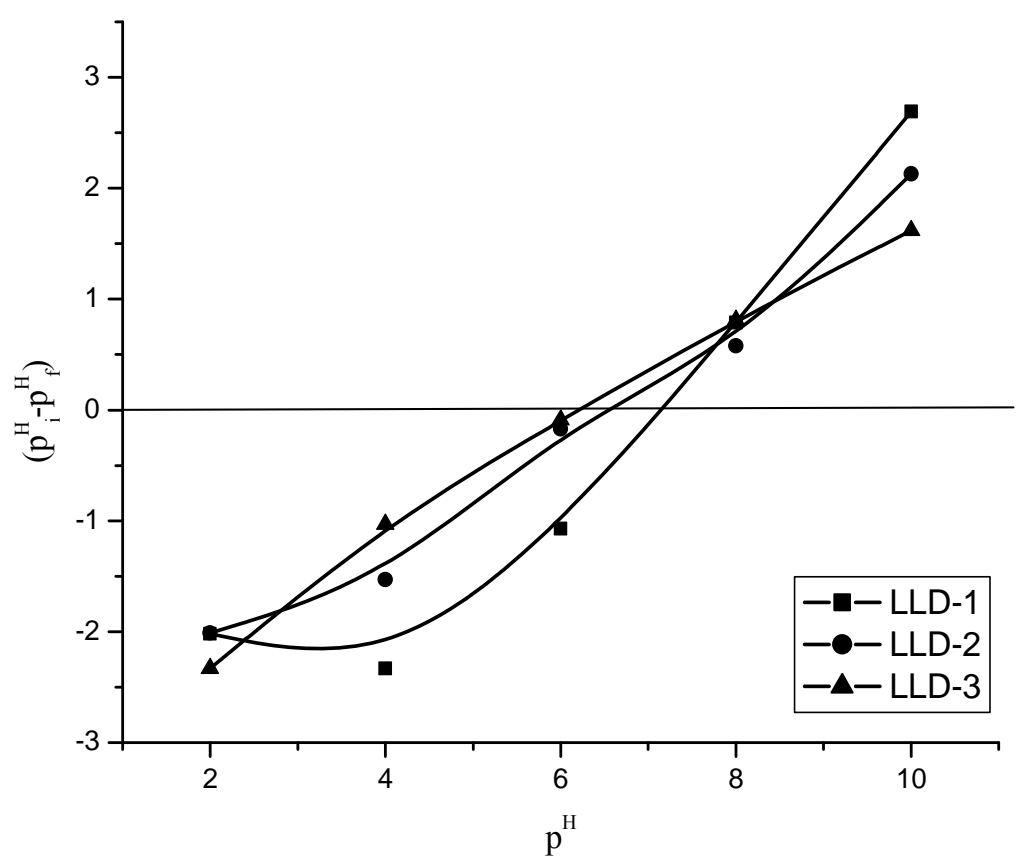

Figure 3. Zero point charge curve of LLD-1, LLD-2 and LLD-3.

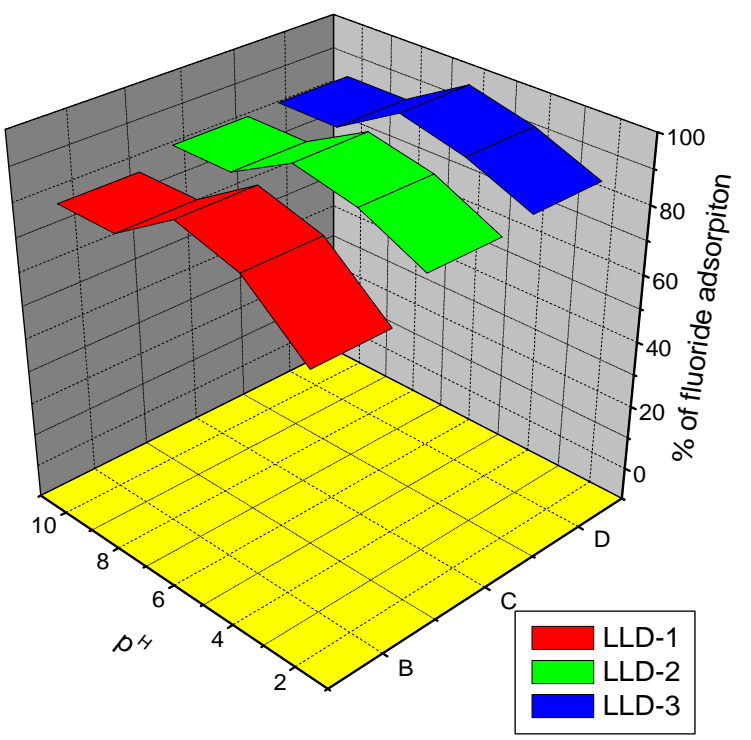

(a)

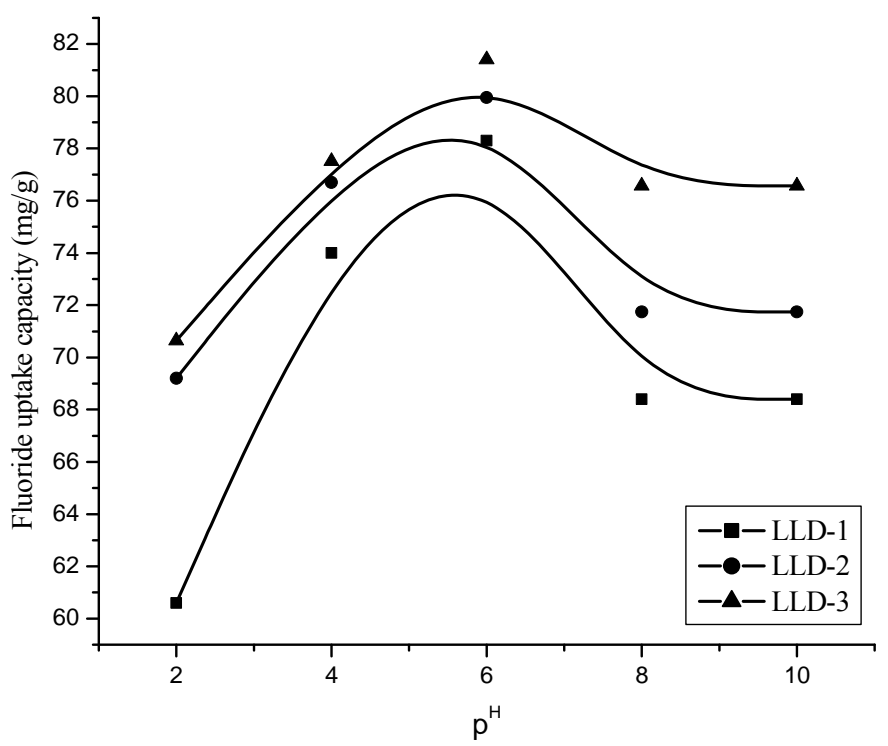

(b)

Figure 4. (a) Effect of $\mathrm{p}^{\mathrm{H}}$ on \% of fluoride adsorption. (Initial fluoride concentration of $10 \mathrm{ppm}$; adsorbent dose $0.05 \mathrm{~g} / \mathrm{L}$ of solution; contact time of $60 \mathrm{~min}$, stirring rate $550 \mathrm{rpm}$, temperature $303 \mathrm{~K}$ ). (b) Effect of $\mathrm{p}^{\mathrm{H}}$ on fluoride uptake capacity. (Initial fluoride concentration of $10 \mathrm{ppm}$; adsorbent dose $0.05 \mathrm{~g} / \mathrm{L}$ of solution; contact time of $60 \mathrm{~min}$, stirring rate $550 \mathrm{rpm}$, temperature $303 \mathrm{~K})$.

concentration is the main driving force behind overcoming all mass transfer resistance of the fluoride, between the aqueous and solid phases [18]. This phenomena lead to increase the equilibrium sorption, until whole adsorbent saturation was achieved [14]. In fluoride adsorption isotherm study the equilibrium data isotherm analysis onto LLD-1, LLD-2 and LLD-3 at pH 6.0 and $303 \mathrm{~K}$ temperature were analyzed using Langmuir, Freundlich,
$\mathrm{D}-\mathrm{R}$ and Tempkin isotherms. The isotherm parameters with their linear form are listed in Table 2. The maximum adsorption capacity of fluoride $\left(q_{\max }\right.$, from Langmuir model) onto LLD-3 surface is higher $(38.46 \mathrm{mg} / \mathrm{g})$ than LLD-2 and LLD-1 which correspond to complete monolayer coverage. The value of $\mathrm{R}_{\mathrm{L}}$ is also more in LLD-3 than other indicating better adsorbent. According to Freundlich isotherm the value of " $n$ " is high in LLD-2 


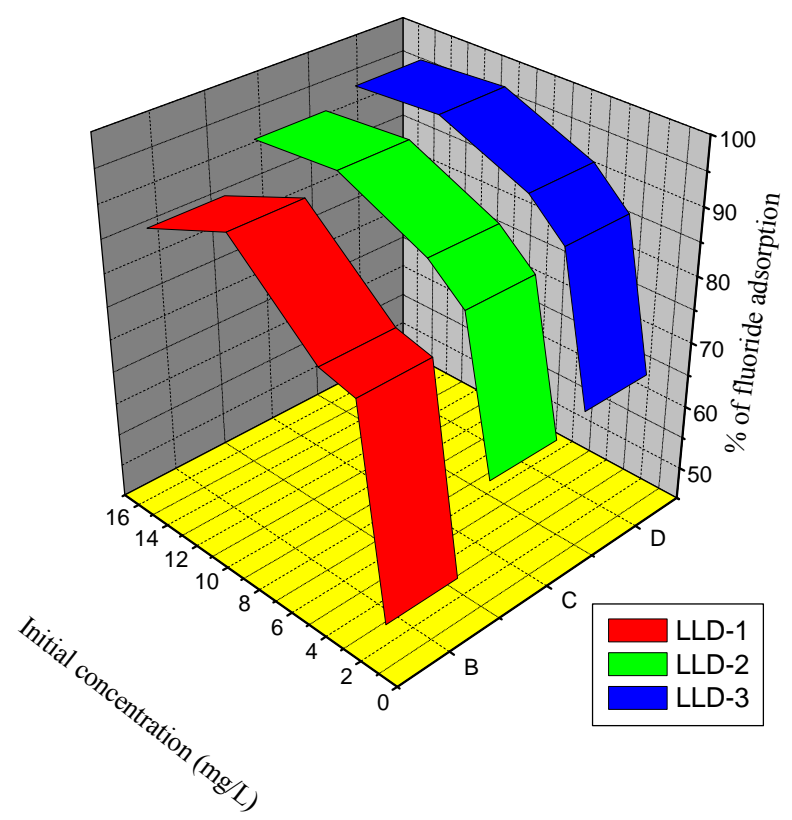

(a)

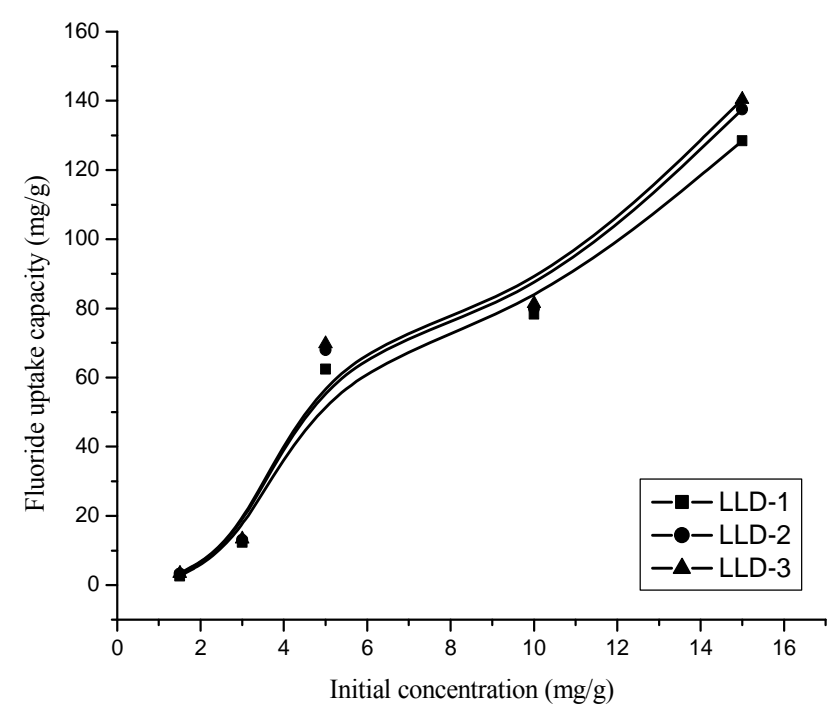

(b)

Figure 5. (a) Effect of initial concentration on \% of fluoride adsorption (pH 6.0; adsorbent dose 0.05 g/L of solution; contact time of $60 \mathrm{~min}$, stirring rate $550 \mathrm{rpm}$, temperature $303 \mathrm{~K}$ ). (b) Effect of initial concentration on fluoride uptake capacity. (pH 6.0 ; adsorbent dose $0.05 \mathrm{~g} / \mathrm{L}$ of solution; contact time of $60 \mathrm{~min}$, stirring rate $550 \mathrm{rpm}$, temperature $303 \mathrm{~K}$ ).

Table 2. Parameters of isotherm models of fluoride adsorption onto LLD-1, LLD-2 and LLD-3.

\begin{tabular}{|c|c|c|c|}
\hline Isotherm models & LLD-1 & LLD-2 & LLD-3 \\
\hline \multirow{4}{*}{ Langmuir } & $\mathrm{K}_{\mathrm{L}}=0.072$ & $\mathrm{~K}_{\mathrm{L}}=0.204$ & $\mathrm{~K}_{\mathrm{L}}=0.083$ \\
\hline & $\mathrm{R}_{\mathrm{L}}=0.93$ & $\mathrm{R}_{\mathrm{L}}=0.83$ & $\mathrm{R}_{\mathrm{L}}=0.92$ \\
\hline & $\mathrm{q}_{\mathrm{m}}=7.63$ & $\mathrm{q}_{\mathrm{m}}=27.03$ & $\mathrm{q}_{\mathrm{m}}=38.46$ \\
\hline & $\mathrm{R}^{2}=0.84$ & $\mathrm{R}^{2}=0.98$ & $\mathrm{R}^{2}=0.99$ \\
\hline \multirow{3}{*}{ Freundlich } & $\mathrm{K}_{\mathrm{f}}=0.45$ & $\mathrm{~K}_{\mathrm{f}}=0.035$ & $\mathrm{~K}_{\mathrm{f}}=0.036$ \\
\hline & $\mathrm{n}=1.72$ & $\mathrm{n}=6.06$ & $\mathrm{n}=6.53$ \\
\hline & $\mathrm{R}^{2}=0.73$ & $\mathrm{R}^{2}=0.96$ & $\mathrm{R}^{2}=0.96$ \\
\hline \multirow{4}{*}{ D-R } & $\mathrm{q}_{\max }=42.5$ & $\mathrm{q}_{\max }=27.41$ & $\mathrm{q}_{\max }=27.03$ \\
\hline & $\mathrm{K}_{\mathrm{DR}}=0.123$ & $\mathrm{~K}_{\mathrm{DR}}=0.01$ & $\mathrm{~K}_{\mathrm{DR}}=0.007$ \\
\hline & $\mathrm{E}_{\mathrm{S}}=2.85$ & $\mathrm{E}_{\mathrm{S}}=10$ & $\mathrm{E}_{\mathrm{S}}=11.95$ \\
\hline & $\mathrm{R}^{2}=0.94$ & $\mathrm{R}^{2}=0.92$ & $\mathrm{R}^{2}=0.92$ \\
\hline \multirow{3}{*}{ Tempkin } & $\mathrm{B}_{1}=5.18$ & $\mathrm{~B}_{1}=5.44$ & $\mathrm{~B}_{1}=4.79$ \\
\hline & $\mathrm{K}_{\mathrm{T}}=9.43$ & $\mathrm{~K}_{\mathrm{T}}=1.71$ & $\mathrm{~K}_{\mathrm{T}}=1.81$ \\
\hline & $\mathrm{R}^{2}=0.76$ & $\mathrm{R}^{2}=0.89$ & $\mathrm{R}^{2}=0.89$ \\
\hline
\end{tabular}

and LLD-3, which also indicates both (6.06 and 6.53 respectively) adsorbents are more effective in fluoride adsorption process than LLD-1. The maximum adsorpiton capacity $\left(q_{\max }\right)$ obtained from D-R isotherm of LLD-1, LLD-2 and LLD-3 are 4.25, 27.41, 27.03 respectively lower than the value of adsorption capacity obtained from Langmuir isotherm. D-R isotherm gives $\beta$ constant, and idea about the mean free energy $\left(\mathrm{Es}, \mathrm{kJ} \cdot \mathrm{mol}^{-1}\right)$ of adsorbate when it is transferred to the surface of the solid from infinity in the solution. The Es value of LLD-1, LLD-2 and LLD-3 are 2.85, 10 and 11.95 directing the physical adsorption mechanism of fluoride onto these adsorbents [22]. Tempkin isotherm constant are shown in Table 2. From the isotherm analysis, it is clear that adsorption nature of fluoride onto LLD-1, LLD-2 and LLD-3 adsorbents best fitted to Langmuir and D-R iso- 
therm model which suggests uniform binding energy on the whole surface of the adsorbents. These results also signify that fluoride ions were adsorbed by a monolayer formation.

\subsection{Effect of Adsorbent Dose}

At lower adsorbent dose, Figure 6(a) shows in case of LLD-1, LLd-2 and LLD-3 percentage of fluoride adsorption is low but fluoride uptake capacity is high (Figure 6(b)). The B-Sp line as flat suggesting the highest fluoride adsorption occurs at $0.1 \mathrm{~g} / \mathrm{L}$ and the followings remains constant. This is probably due to the overlapping of active sites at higher dosage and subsequently reducing the net surface area [23].

\subsection{Effect of Contact Time}

Figures 7(a) and (b) indicate the variations of fluoride adsorption by LLD-1, LLd-2 and LLD-3 adsorbents with respect to contact time. It has been revealed form this study that percentage of fluoride adsorption and adsorption capacity both increased due to increasing of contact time and the curve gets equilibrium after 120 minutes. The removal efficiency of fluoride was increased which increasing time is probably due to participation of specific functional groups and active surface sites on adsorbents surfaces [17,24]. Similar findings were also reported by [24] for fluoride removal on biomass of Spirogyra sp. However, removal decreased after 120 minutes indicating the possible monolayer of fluoride ions on the outer surface, pores of both the adsorbents and pore diffusion onto inner surface of adsorbent particles [14].

\subsection{Effect of Stirring Rate}

The stirring rate in adsorption study is an essential parameter which can enhance a certain turbulance insuring a good contact between the adsorbate and adsorbent [24]. To determine the effect of stirring rate $250 \mathrm{rpm}$ to 850 rpm speeds were chosen. Figures 8(a) and (b) show fluoride adsorption occurred rapidly in the first stirring rate from $250 \mathrm{rpm}$ and at $550 \mathrm{rpm}$ the fluoride adsorption rate and uptake capacity both are highest. Then beyond $550 \mathrm{rpm}$ both remain more or less constant in case of these adsorbents due to higher speeds better contact between the fluoride ions and adsorbent surface is possible. In this study at $550 \mathrm{rpm}$, LLD-3 shows better fluoride adsorption rate $(98.8 \%)$ and uptake capacity $(41.4 \mathrm{mg} / \mathrm{g})$ than other.

\subsection{Effect of Temperature and Thermodynamic Study}

The influence of temperature in adsorption process is very important because increasing the temperature induces a decrease in the adsorption capacity of fluoride on the adsorbent surface. Figures 9(a) and (b) shows reducing percentage of both fluoride adsorption and adsorption capacity due to increase of temperature beyond 313 $\mathrm{K}$ to $333 \mathrm{~K}$. From Table 3 the values of $\Delta \mathrm{G}^{0}$ (Gibbs free energy of adsorption, $\mathrm{kJ} \cdot \mathrm{mol}^{-1}$ ) at different temperatures, indicates the feasibility of the process and the spontaneous nature of fluoride ions onto adsorbents [22]. In case of tested adsorbents, during values of $\Delta G^{0}$ due to increasing temperatures suggests the lower temperature makes the adsorption easier [22]. The value of $\Delta \mathrm{H}^{0}$
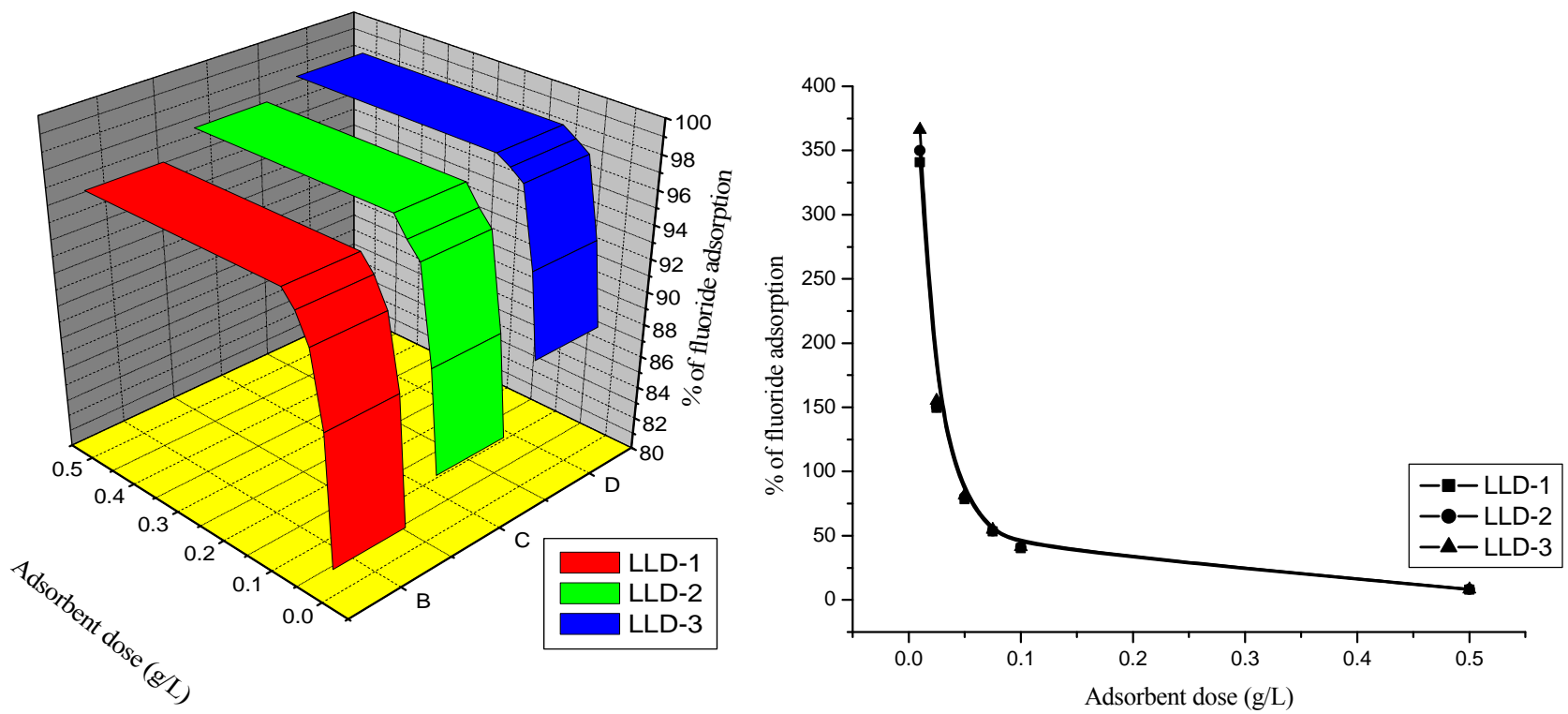

Figure 6. (a) Effect of adsorbent dose (g/L) on \% of fluoride adsorption. (Initial fluoride concentration of $10 \mathrm{ppm}$; pH 6.0; contact time of $60 \mathrm{~min}$, stirring rate $550 \mathrm{rpm}$, temperature $303 \mathrm{~K}$ ). (b) Effect of adsorbent dose (g/L) on fluoride uptake capacity. (Initial fluoride concentration of $10 \mathrm{ppm}$; pH 6.0; contact time of $60 \mathrm{~min}$, stirring rate $550 \mathrm{rpm}$, temperature $303 \mathrm{~K}$ ). 

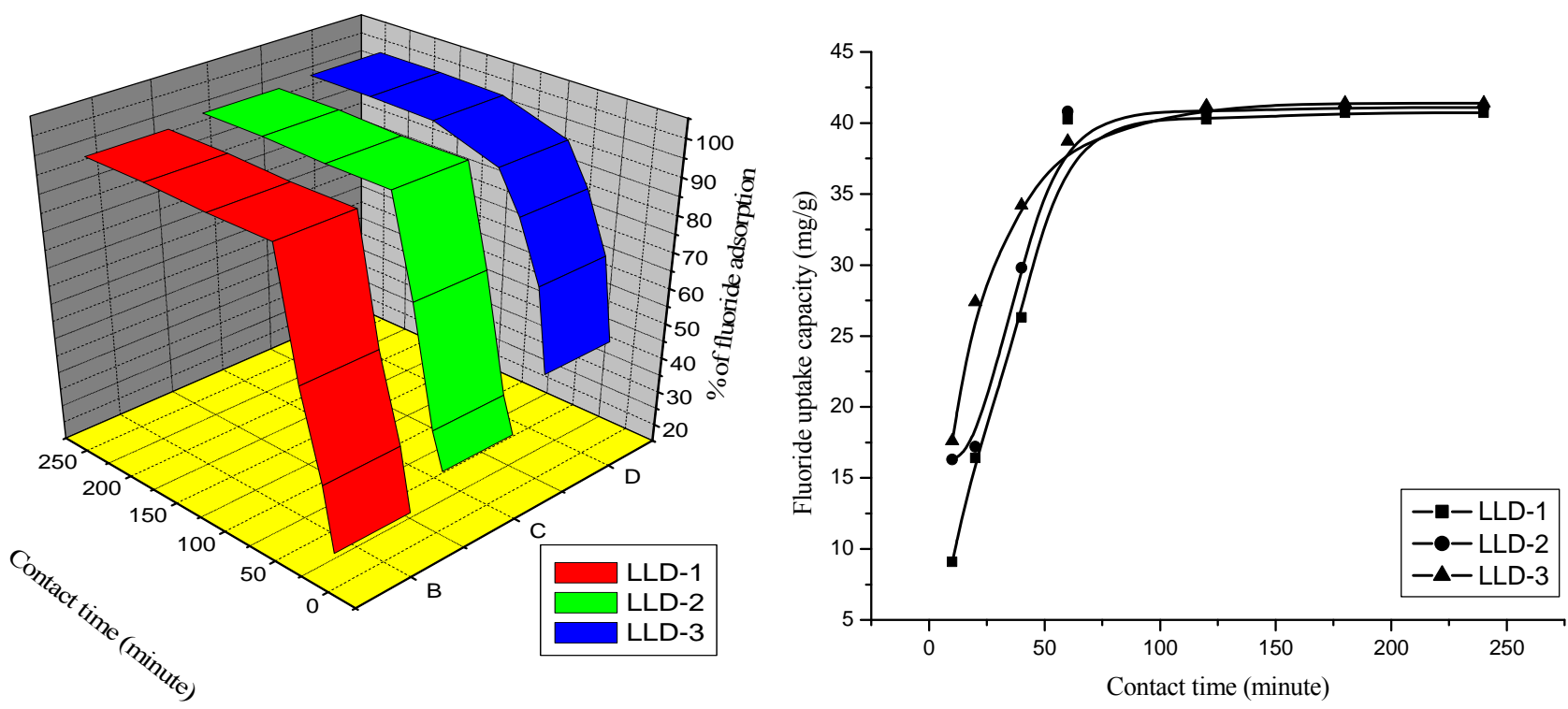

Figure 7. (a) Effect of contact time (minute) on \% of fluoride adsorption. (Initial fluoride concentration of $10 \mathrm{ppm}$; pH 6.0; adsorbent dose $0.1 \mathrm{~g} / \mathrm{L}$; stirring rate $550 \mathrm{rpm}$, temperature $303 \mathrm{~K}$ ). (b) Effect of contact time (minute) on fluoride uptake capacity.(Initial fluoride concentration of $10 \mathrm{ppm}$; $\mathrm{pH}$ 6.0; adsorbent dose $0.1 \mathrm{~g} / \mathrm{L}$; stirring rate $120 \mathrm{rpm}$, temperature $303 \mathrm{~K}$ ).
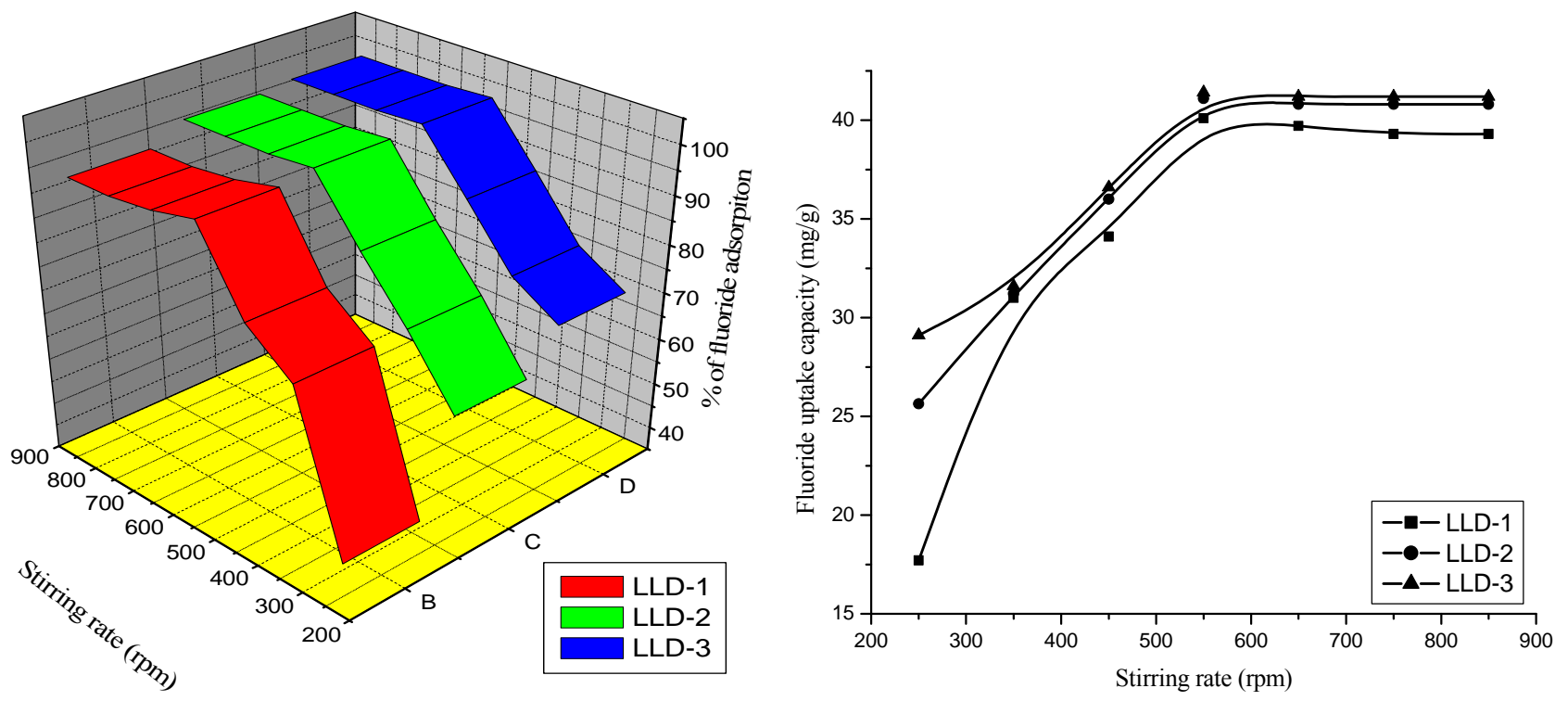

Figure 8. (a) Effect of stirring rate (rpm) on \% of fluoride adsorption (Initial fluoride concentration of $10 \mathrm{ppm}$; $\mathbf{p H ~ 6 . 0 ; ~ a d - ~}$ sorbent dose $0.1 \mathrm{~g} / \mathrm{L}$; contact time $180 \mathrm{~min}$; temperature $303 \mathrm{~K}$ ). (b) Effect of stirring rate (rpm) on fluoride uptake capacity. (Initial fluoride concentration of $10 \mathrm{ppm}$; pH 6.0; adsorbent dose $0.1 \mathrm{~g} / \mathrm{L}$; contact time $180 \mathrm{~min}$; temperature $303 \mathrm{~K}$ ).

(enthalpy change of adsorption, $\mathrm{kJ} \cdot \mathrm{mol}^{-1}$ ) and $\Delta \mathrm{S}^{0}$ (entropy change of adsorption, $\mathrm{kJ} \cdot \mathrm{mol}^{-1}$ ) are also shown in Table 3, which indicate fluoride adsorption process onto LLD-1, LLD-2 and LLD-3 are explained by the exothermic in nature and the negative values of $\Delta S^{0}$ indicate that during the fluoride adsorption the solid-solution interface researches a more organized structure (decrease of randomness).

\subsection{Adsorption Kinetics Study}

The experimental parameters $(\mathrm{pH}$, initial concentration, adsorbent dose, contact time, stirring rate and temperature) are responsible for their potential impact on percentage of fluoride adsorption and uptake capacity. These parameters also greatly influence on the external surface available for fluoride ion binding, diffusion properties and concentration gradient. Table 4 shows the values of pseudo-first, pseudo-second order kinetic constants and intraparticle diffusion model. Comparing these models, the fluoride adsorption is well fitted to the pseudo-second order kinetic model and the adsorption rate $\left(\mathrm{h}, \mathrm{mg} \cdot \mathrm{g}^{-1} \cdot \mathrm{min}^{-1}\right)$ was calculated shown in Table 4. 

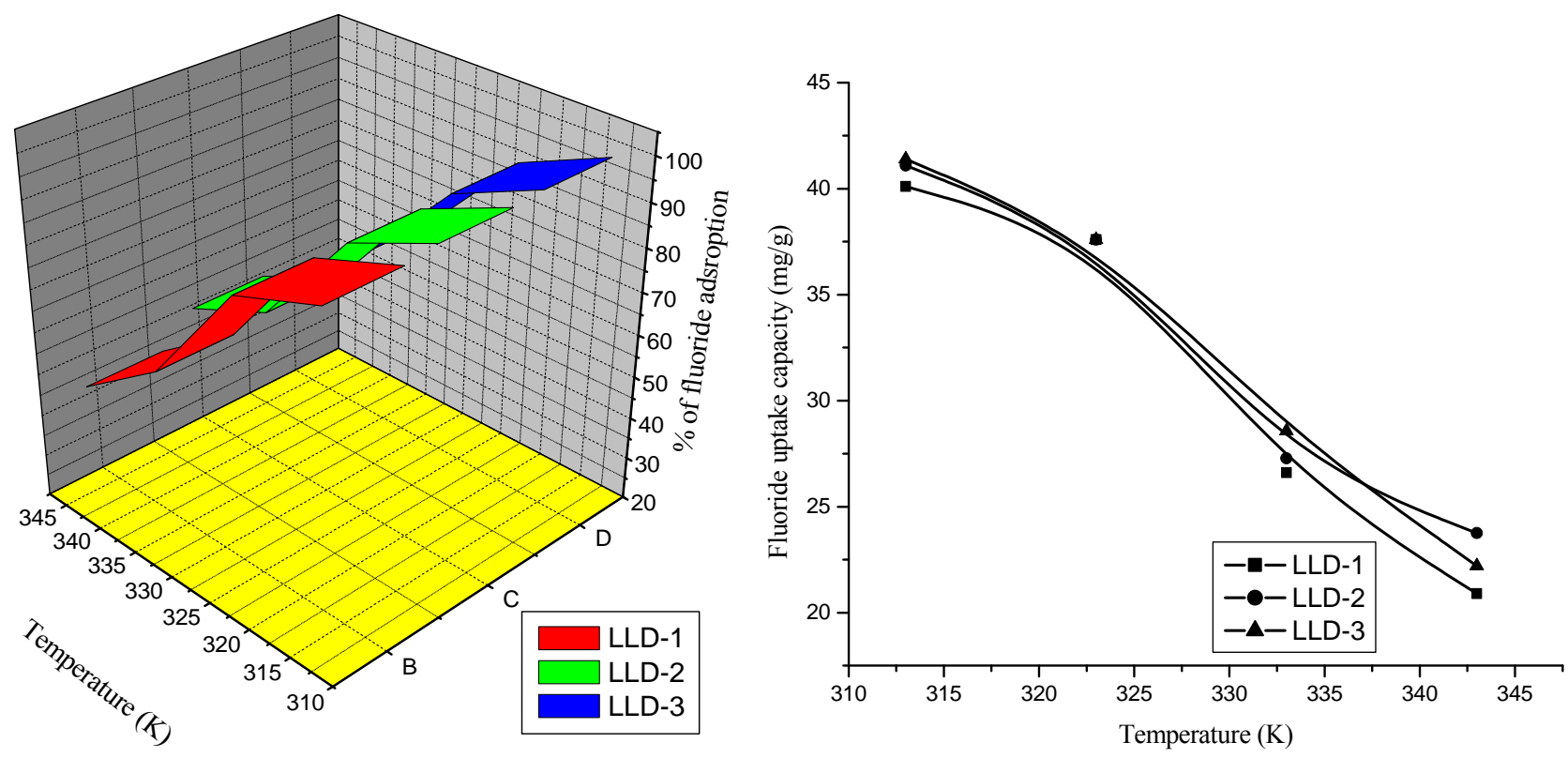

Figure 9. (a) Effect of temperature (K) on \% of fluoride adsorption. (Initial fluoride concentration of $10 \mathrm{ppm}$; pH 6.0; adsorbent dose $0.1 \mathrm{~g} / \mathrm{L}$; contact time $180 \mathrm{~min}$; stirring rate $650 \mathrm{rpm})$. (b) Effect of temperature (K) on fluoride uptake capacity. (Initial fluoride concentration of 10 ppm; pH 6.0; adsorbent dose 0.1 g/L; contact time $180 \mathrm{~min}$; stirring rate $650 \mathrm{rpm}$ ).

Table 3. Thermodynamic parameters of fluoride adsorption onto LLD-1, LLD-2 and LLD-3.

\begin{tabular}{ccccc}
\hline Thermodynamic parameters & Temperature $(\mathrm{K})$ & LLD-1 & LLD-2 & LLD-3 \\
\hline & 303 & -7.792 & -9.321 & -10.01 \\
$\Delta \mathrm{G}^{0}$ & 313 & -5.332 & -6.191 & -6.41 \\
& 323 & -2.872 & -3.061 & -2.81 \\
$\Delta \mathrm{H}^{0}$ & 333 & -0.412 & -0.069 & -0.79 \\
$\Delta \mathrm{S}^{0}$ & & -82.33 & -104.16 & -119.09 \\
\hline
\end{tabular}

The value of $h$ is high in LLD-3, LLD-2 and LLD-1 respectively which indicates all tested adsorbents are effective in fluoride adsorption.

\subsection{Box-Behnken Statistical Analysis}

In the present study, Box Behnken design was used to predict the fluoride adsorption rate. The complete design model was composed of 17 experimental runs with three replicates at the center points. The significant of the model was justified by the ANOVA. The ANOVA of fluoride adsorption rate is given in Tables 5-7. The model F-value is the ratio of mean square for the individual term to the mean square for the residual. The Prob $>\mathrm{F}$ value is the probability of F-statistics value and is used to test the null hypothesis. The parameters having an F-statistics probability value less than 0.05 are said to be significant. The $\mathrm{pH}$ of the solution, adsorbent dose, contact time, initial fluoride concentration, stirring rate and temperature are very effective in fluoride adsorption. Among these output variables, $\mathrm{pH}$ of the solution, initial fluoride concentration, contact time and temperature had a significant effect on fluoride adsorption. Once the optimization was ever the experimental and model predicted values of the response variables were compared. The plot between experimental (actual) and predicted values of fluoride adsorption rate is shown in Figures 10(a), (b) and (c). A good correlation between input and output variables are also shown by the model.

\subsection{Effects of Experimental Parameters on Fluoride Adsorption}

The effects of different experimental parameters such as solution $\mathrm{pH}$, initial fluoride concentration, contact time and temperature on the fluoride adsorption is shown in Figures 11 (a)-(i). The fluoride adsorption capacity was increased with increase in initial fluoride concentration, contact time and decreased in solution $\mathrm{pH}$ and temperature. The adsorption of fluoride adsorption favors comparatively at low $\mathrm{pH}$ and room temperature. Tables 5-7 show the model F-value of LLD-1, LLD-2 and 
Table 4. Parameters of kinetic models of fluoride adsorption onto LLD-1, LLD-2 and LLD-3.

\begin{tabular}{|c|c|c|c|}
\hline Kinetic models & LLD-1 & LLD-2 & LLD-3 \\
\hline \multirow{3}{*}{ Pseudo-first-order } & $\mathrm{q}_{\mathrm{e} 1}=2.33$ & $\mathrm{q}_{\mathrm{e} 1}=1.01$ & $\mathrm{q}_{\mathrm{e} 1}=1.14$ \\
\hline & $\mathrm{K}_{\mathrm{ad} 1}=0.009$ & $\mathrm{~K}_{\mathrm{ad} 1}=0.01$ & $\mathrm{~K}_{\mathrm{ad} 1}=0.014$ \\
\hline & $\mathrm{R}^{2}=0.25$ & $\mathrm{R}^{2}=0.8$ & $\mathrm{R}^{2}=0.41$ \\
\hline \multirow{3}{*}{ Pseudo-second-order } & $\mathrm{q}_{\mathrm{e} 2}=47.62$ & $\mathrm{q}_{\mathrm{e} 2}=45.45$ & $\mathrm{q}_{\mathrm{e} 2}=48.91$ \\
\hline & $\mathrm{K}_{\mathrm{ad} 2}=0.07$ & $\mathrm{~K}_{\mathrm{ad} 2}=0.001$ & $\mathrm{~K}_{\mathrm{ad} 2}=0.002$ \\
\hline & $\mathrm{R}^{2}=0.99$ & $\mathrm{R}^{2}=0.99$ & $\mathrm{R}^{2}=0.99$ \\
\hline \multirow{3}{*}{ Intra-particle diffusion } & $\mathrm{K}_{\mathrm{it}}=2.03$ & $\mathrm{~K}_{\mathrm{it}}=1.13$ & $\mathrm{~K}_{\mathrm{it}}=0.691$ \\
\hline & $\mathrm{I}=4.07$ & $\mathrm{I}=25.44$ & $\mathrm{I}=31.92$ \\
\hline & $\mathrm{R}^{2}=0.97$ & $\mathrm{R}^{2}=0.79$ & $\mathrm{R}^{2}=0.72$ \\
\hline
\end{tabular}

Table 5. Analysis of variance for fluoride adsorption rate onto LLD-1. ANOVA for response surface Quadratic Model Analysis of variance table [Partial sum of squares-Type III].

\begin{tabular}{|c|c|c|c|c|c|}
\hline $\begin{array}{l}\text { p-value source } \\
\text { prob }>F\end{array}$ & Sum of Squares & df & Mean Square & $\begin{array}{c}\mathrm{F} \\
\text { Value }\end{array}$ & $\begin{array}{c}\text { P } \\
\text { Probability }\end{array}$ \\
\hline $\begin{array}{c}\text { Model } \\
<0.0001\end{array}$ & 14578.51 & 9 & 1619.83 & 65.45 & $<0.0001$ \\
\hline $\begin{array}{c}\text { A-initial } \\
\text { concentration }\end{array}$ & 2614.10 & 1 & 2614.10 & 105.62 & $<0.0001$ \\
\hline 0.0001 B-pH & 3110.35 & 1 & 3110.35 & 125.67 & $<0.0001$ \\
\hline $\begin{array}{c}\text { C-contact time } \\
0.0001\end{array}$ & 1404.50 & 1 & 1404.50 & 56.75 & $<0.0001$ \\
\hline $\begin{array}{c}\mathrm{AB} \\
0.0001\end{array}$ & 1482.25 & 1 & 1482.25 & 59.89 & $<0.0001$ \\
\hline $\begin{array}{c}\mathrm{AC} \\
0.0541\end{array}$ & 132.25 & 1 & 132.25 & 5.34 & $<0.0541$ \\
\hline $\begin{array}{c}\mathrm{BC} \\
0.0727\end{array}$ & 110.25 & 1 & 110.25 & 4.45 & $<0.0727$ \\
\hline $\begin{array}{c}\mathrm{A} 2 \\
0.0001\end{array}$ & 1615.50 & 1 & 1615.5 & 65.27 & \\
\hline $\begin{array}{c}\mathrm{B} 2 \\
0.0001\end{array}$ & 2556.64 & 1 & 2556.64 & 103.29 & \\
\hline $\begin{array}{c}\mathrm{C} 2 \\
0.0002\end{array}$ & 1259.03 & 1 & 1259.03 & 50.87 & \\
\hline Residual & 173.26 & 7 & 24.75 & & \\
\hline $\begin{array}{c}\text { Lack of fit } \\
0.1999\end{array}$ & 171.26 & 6 & 28.54 & 14.27 & $<0.1999$ \\
\hline Pure error & 2.00 & 1 & 2.00 & & \\
\hline Cor Total & 14751.76 & 16 & & & \\
\hline $\begin{array}{c}\text { Std. Dev. } \\
0.9883\end{array}$ & & 4.98 & & R-Squared & \\
\hline $\begin{array}{c}\text { Mean } \\
0.9732\end{array}$ & & 52.88 & & Adj R-Squared & \\
\hline $\begin{array}{l}\text { C.V. \% } \\
0.9174\end{array}$ & & 9.41 & & Pred R-Squared & \\
\hline Press & & 1219.09 & & Adeq Precision & 21.296 \\
\hline
\end{tabular}


Table 6. Analysis of variance for fluoride adsorption rate onto LLD-2.

\begin{tabular}{|c|c|c|c|c|c|}
\hline p-value source prob $>F$ & Sum of Squares & $\mathrm{df}$ & Mean Square & F Value & P Probability \\
\hline Model & 6387.32 & 9 & 709.70 & 248.87 & $<0.0001$ \\
\hline $\begin{array}{l}\text { A-initial concentration } \\
\quad<0.0001\end{array}$ & 668.52 & 1 & 668.52 & 243.43 & $<0.0001$ \\
\hline $\begin{array}{l}\text { B-contact time } \\
<0.0001\end{array}$ & 1891.13 & 1 & 1891.31 & 663.15 & $<0.0001$ \\
\hline $\begin{array}{l}\text { C-temp } \\
<0.0001\end{array}$ & 1081.13 & 1 & 1081.13 & 379.11 & $<0.0001$ \\
\hline $\mathrm{AB} 2.25$ & 1 & 2.25 & 0.79 & 0.4039 & \\
\hline AC 56.25 & 1 & 56.25 & 19.72 & 0.0030 & \\
\hline BC 441.00 & 1 & 441.00 & 154.64 & $<0.0001$ & \\
\hline A2 30.81 & 1 & 30.81 & 10.80 & 0.0134 & \\
\hline C2 242.37 & 1 & 242.37 & 84.99 & $<0.0001$ & \\
\hline Residual & 19.96 & 7 & 2.85 & & \\
\hline Lack of fit 0.1999 & 71.20 & 4 & 4.30 & 4.67 & 0.1182 \\
\hline Pure error & 2.76 & 3 & 4.30 & & \\
\hline Cor Total & 6407.28 & 16 & & & \\
\hline Std. Dev. 0.9969 & & 4.98 & & R-Squared & \\
\hline Mean 0.9929 & & 57.46 & & Adj R-Squared & \\
\hline C.V. $\% 0.9641$ & & 2.94 & & Pred R-Squared & \\
\hline Press & & 230.16 & & Adeq Precision & 46.152 \\
\hline
\end{tabular}

Table 7. Analysis of variance for fluoride adsorption rate onto LLD-3.

\begin{tabular}{|c|c|c|c|c|c|}
\hline p-value source prob $>F$ & Sum of Squares & $\mathrm{df}$ & Mean Square & F Value & P Probability \\
\hline $\begin{array}{c}\text { Model } \\
<0.0001\end{array}$ & 2784.73 & 14 & 198.91 & 209.93 & $<0.0001$ \\
\hline $\begin{array}{l}\text { A-initial concentration } \\
\quad<0.0001\end{array}$ & 802.32 & 1 & 802.32 & 846.76 & $<0.0001$ \\
\hline $\begin{array}{c}\text { B-pH } \\
<0.0001\end{array}$ & 111.93 & 1 & 111.93 & 118.13 & $<0.0001$ \\
\hline $\begin{array}{l}\text { C-temp } \\
<0.0001\end{array}$ & 247.45 & 1 & 247.45 & 261.16 & $<0.0001$ \\
\hline $\begin{array}{l}\text { D-contact time } \\
\quad<0.0001\end{array}$ & 101.12 & 1 & 101.12 & 106.72 & $<0.0001$ \\
\hline AB 0.0002 & 25.00 & 1 & 25.00 & 26.38 & \\
\hline AC 0.0591 & 4 & 1 & 4 & 4.22 & 0.0591 \\
\hline $\begin{array}{c}\mathrm{AD} \\
0.0051\end{array}$ & 10.42 & 1 & 10.42 & 10.99 & 0.0051 \\
\hline $\begin{array}{c}\mathrm{BC} \\
0.1637\end{array}$ & 2.05 & 1 & 2.05 & 2.16 & 0.1637 \\
\hline $\begin{array}{c}\text { BD } \\
<0.0001\end{array}$ & 210.25 & 1 & 210.25 & 221.9 & $<0.0001$ \\
\hline $\begin{array}{c}\text { CD } \\
0.3217\end{array}$ & 1.00 & 1 & 1.00 & 1.06 & 0.3217 \\
\hline $\begin{array}{c}\mathrm{A} 2 \\
<0.0001\end{array}$ & 167.86 & 1 & 167.86 & 177.16 & $<0.0001$ \\
\hline $\begin{array}{c}\mathrm{B}^{2} \\
<0.0001\end{array}$ & 443.06 & 1 & 443.06 & 464.00 & $<0.0001$ \\
\hline $\begin{array}{c}\mathrm{C} 2 \\
<0.0001\end{array}$ & 42.77 & 1 & 42.77 & 45.14 & $<0.0001$ \\
\hline $\begin{array}{c}\mathrm{D}^{2} \\
<0.0001\end{array}$ & 49.50 & 1 & 49.50 & 52.24 & $<0.0001$ \\
\hline Residual & 13.27 & 14 & 0.95 & & \\
\hline Lack of fit 0.0412 & 12.52 & 10 & 1.25 & 6.67 & 0.0412 \\
\hline Pure error & 0.75 & 4 & 0.19 & & \\
\hline Cor Total & 2798.00 & 28 & & & \\
\hline Std. Dev. 0.9953 & & 0.97 & & R-Squared & 0.9953 \\
\hline Mean 0.9905 & & 75.00 & & Adj R-Squared & 0.9905 \\
\hline C.V. $\% 0.9695$ & & 1.30 & & Pred R-Squared & 0.9695 \\
\hline Press & & 85.23 & & Adeq Precision & 50.456 \\
\hline
\end{tabular}


Design-Expert ${ }^{\circledR}$ Sof tware removal

Color points by value of removal:

$\prod_{13}^{92}$

Design-Expert ${ }^{\circledR}$ Software Removal

Color points by value of Removal:

$\left[\begin{array}{l}92 \\ 56\end{array}\right.$

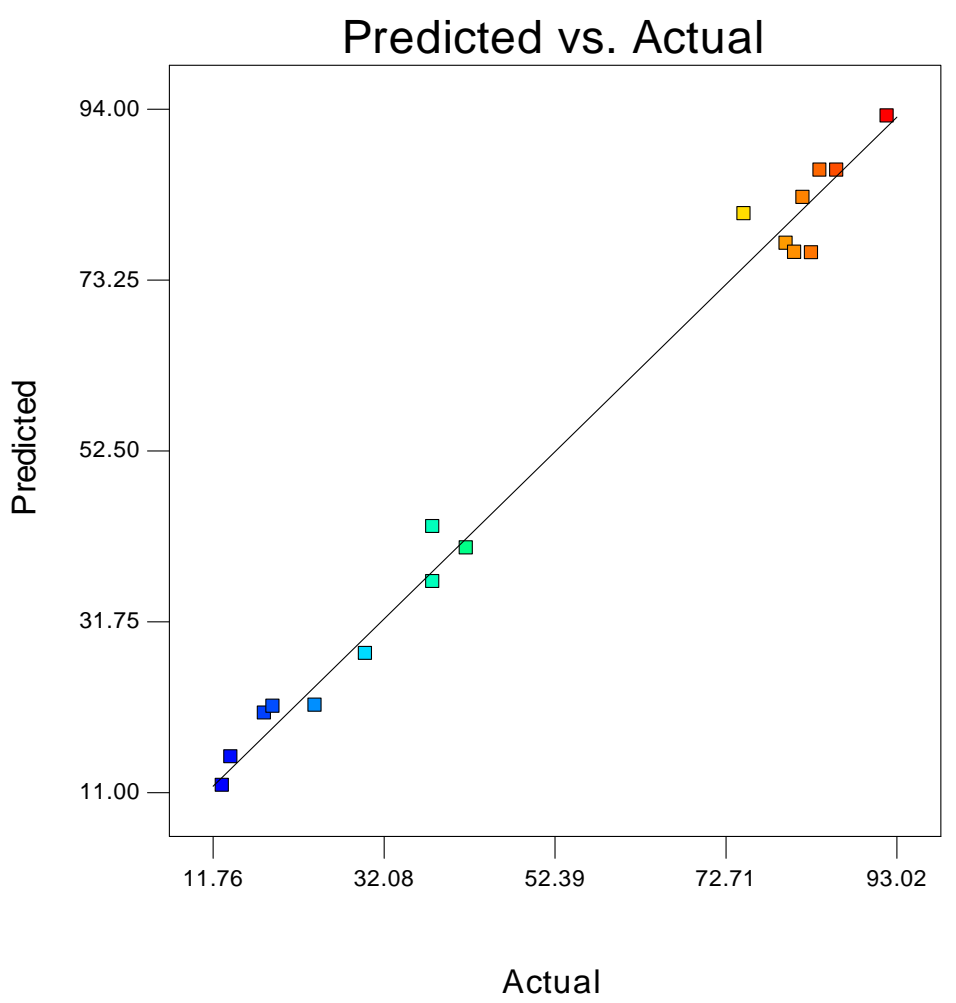

(a)

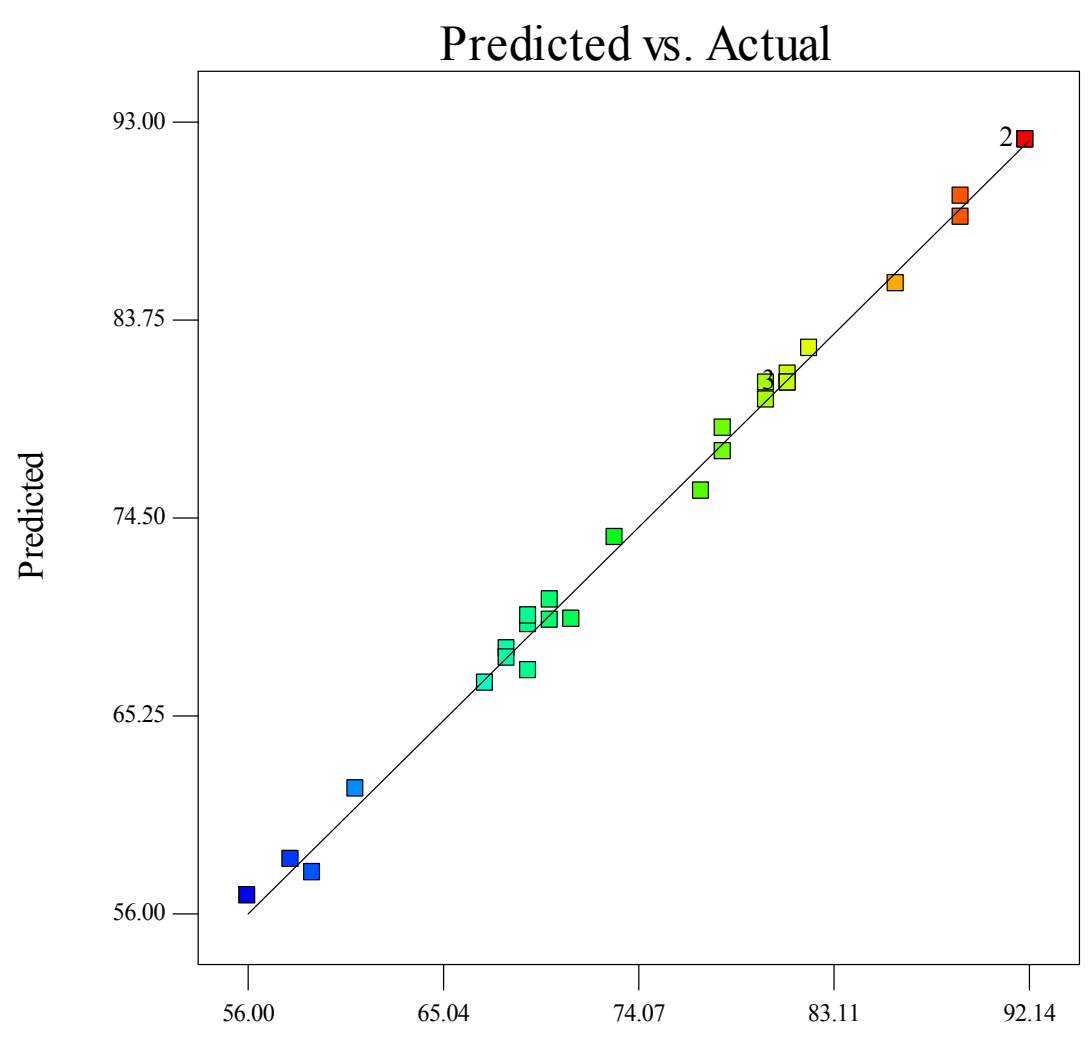

Actual

(b) 
Design-Expert ${ }^{\circledR}$ Software Removal

Color points by value of Removal:

56

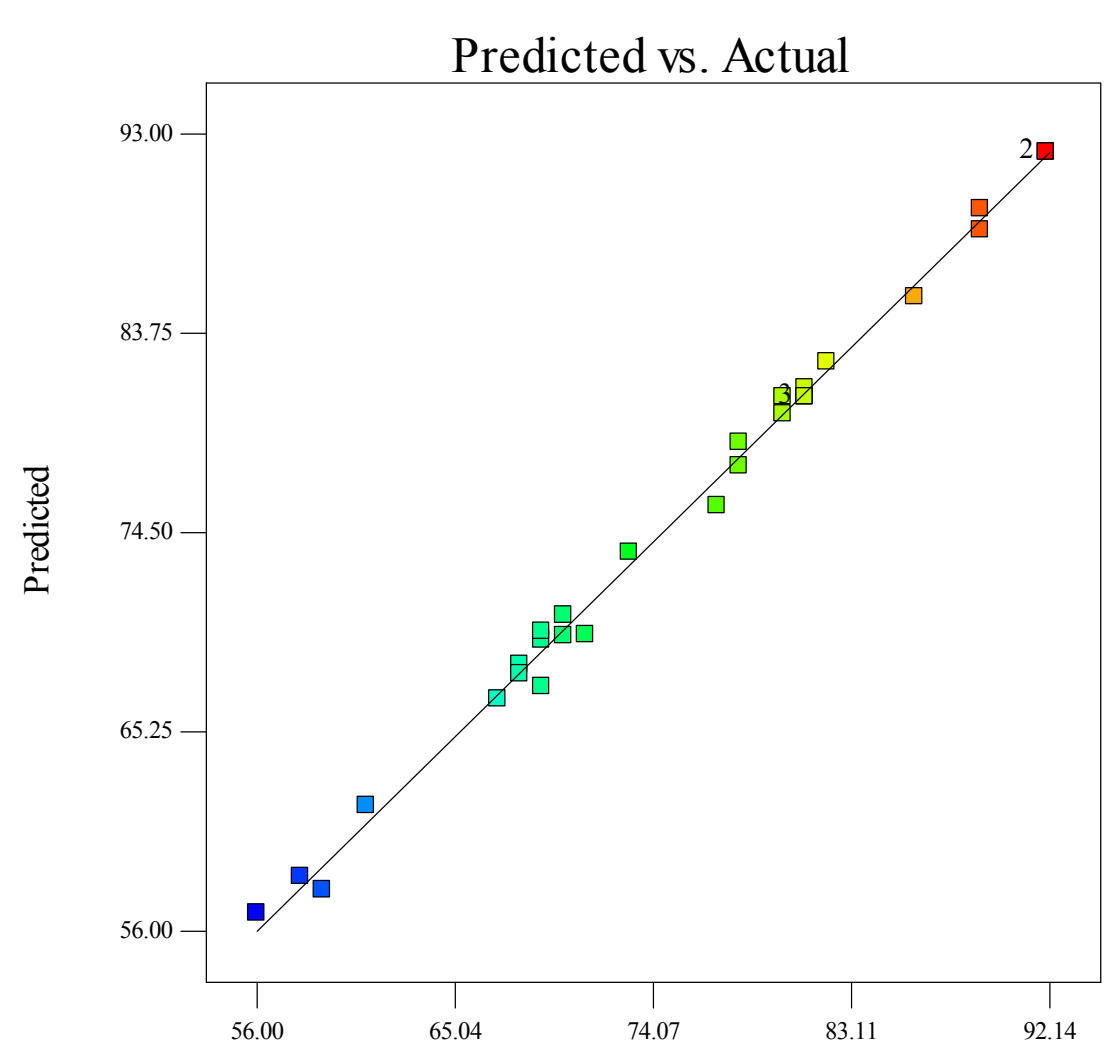

Actual

(c)

Figure 10. The plot of predicted versus actual values for fluoride adsorption rate onto (a) LLD-1, (b) LLD-2, (c) LLD-3.

LLd-3 are 65.45, 248.87 and 209.93 respectively which imply the model is significant. There is only $0.01 \%$ of chance that a "model F value" this large could occur due to noise. The values of "prob $>$ F" less than 0.05 indicate model terms are significant, where values greater than 0.1 direct the model terms are not significant.

\subsection{Optimization of Process Variables}

The numerical optimization was applied to optimize the fluoride adsorption process and the optimum values of various parameters are provided in Table 8. A desirability value of 1.0 was obtained after optimizing the process parameters.

\section{Conclusion}

This work investigated the adsorption of fluoride onto LLD-1, LLD-2 and LLD-3. Experiments were made as a function of different adsorption parameters $(\mathrm{pH}$, initial fluoride concentration, adsorbent dose, contact time and stirring rate and temperature). Response surface methodology by the Box-Behnken model was used to examine the role of three process factors on fluoride removal. It was shown that a second-order polynomial regression model could properly interpret the experimental data with coefficient of determination $\left(\mathrm{R}^{2}\right)$ value of 0.9969 and an $\mathrm{F}$ value of 248.87. The simultaneous optimization of the multiresponse system by desirability function indicated that $92.74 \%, 92.52 \%, 92.24 \%$ adsorption of fluoride can be possible by using the optimal conditions of $\mathrm{pH}$, initial fluoride concentration, contact time and temperature. The Langmuir, Freundlich, D-R and Tempkin isotherm models were used for the description of fluoride adsorption phenomenon. The data were good agreement with both Langmuir and D-R isotherms. The kinetics of fluoride adsorption was controlled by pseudo-second order kinetic model for all the tested adsorbents. However, LLD-1 also showed the agreement with intra-particle diffusion model. The adsorptions of fluoride onto LLD-1, LLD-2 and LLD-3 were found to be exothermic in nature. This study shows that the BoxBehnken model is suitable to optimize the experiments for fluoride removal through adsorption.

\section{Acknowledgements}

Authors express their sincere thanks to Professor J K 
LLD-1

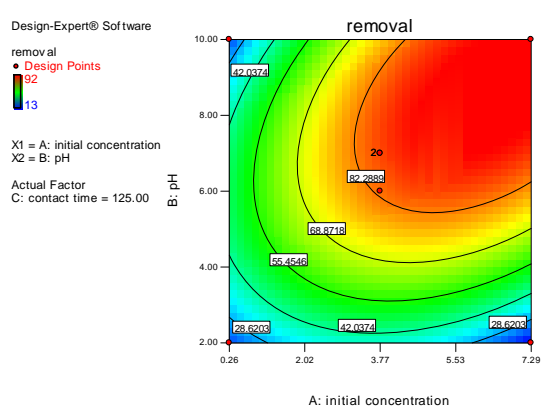

(a)

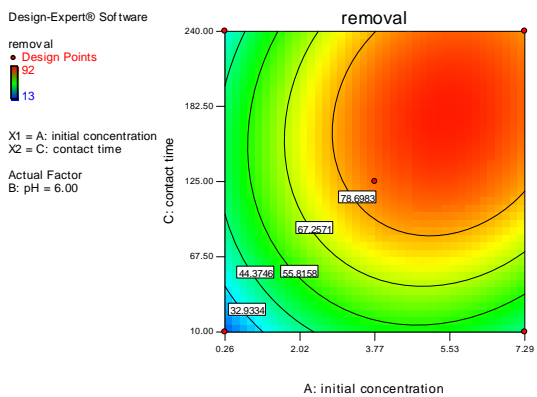

(b)

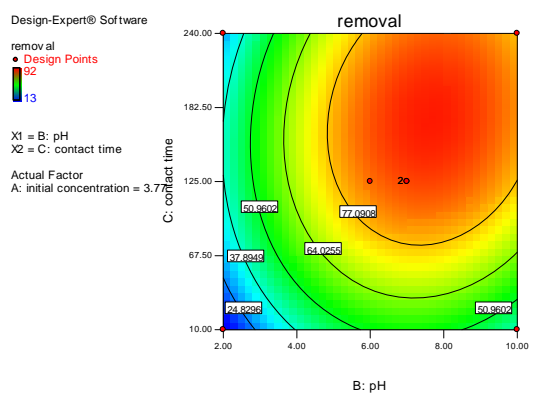

(c)
LLD-2

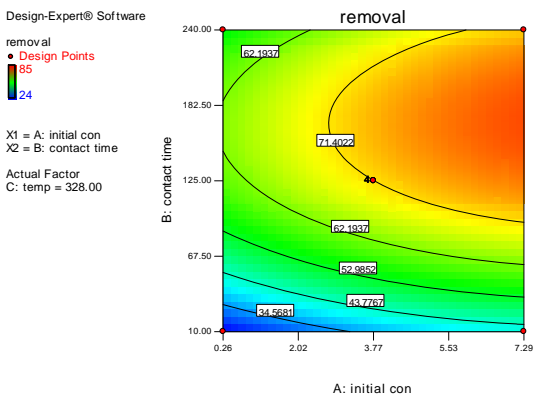

(d)

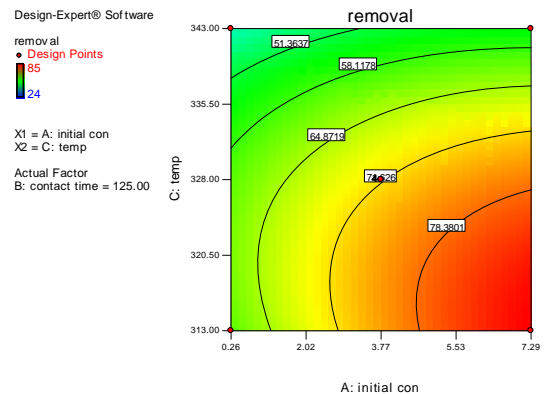

(e)

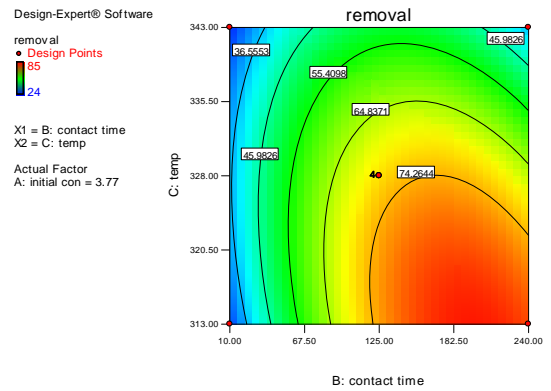

(f)
LLD-3

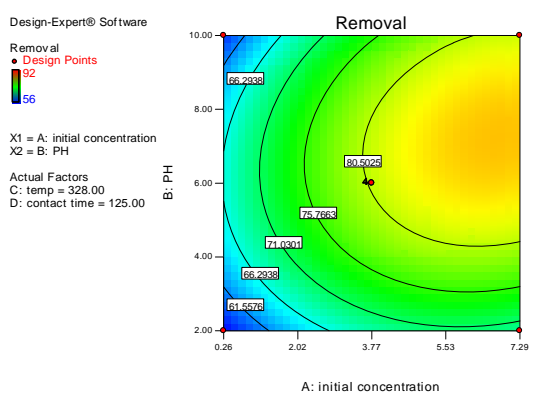

(g)

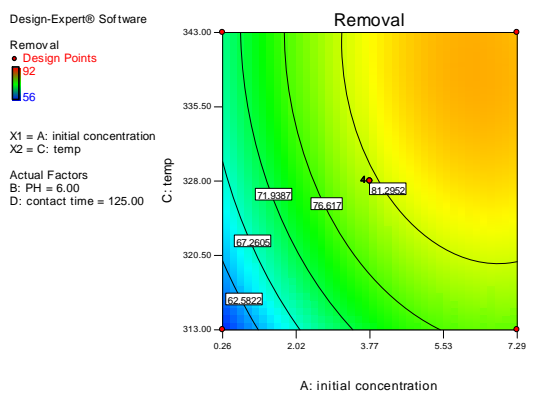

(h)

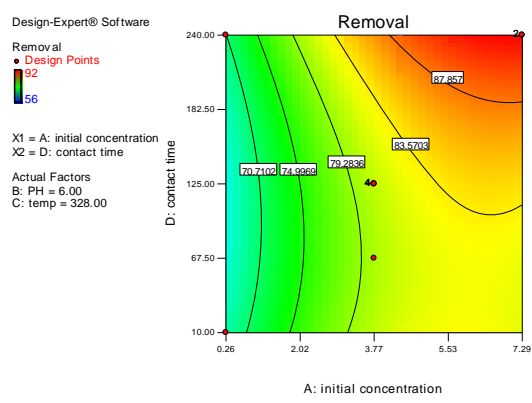

(i)

Figure 11. The effects of (a) and (g) solution $\mathrm{pH}$ and initial fluoride concentration, (b) and (d) and (i) contact time and initial fluoride concentration, (c) contact time and $\mathrm{pH}$, (e) and (h)temperature and initial fluoride concentration, (f) temperature and contact time.

Table 8. The optimum values of the experimental parameters.

\begin{tabular}{|c|c|c|c|}
\hline Parameters & LLD-1 & LLD-2 & LLD-3 \\
\hline $\mathrm{pH}$ & 6.15 & - & 7.34 \\
\hline Contact time (min) & 143.73 & 45.97 & 203.47 \\
\hline Initial concentration $(\mathrm{mg} / \mathrm{L})$ & 6.03 & 2.94 & 6.66 \\
\hline Temperature (K) & - & 328.09 & 336.10 \\
\hline Adsorption & 92.74 & 92.52 & 92.24 \\
\hline
\end{tabular}


Datta for his encouragement and active support of doing such laborious work. Authors also like to express their gratitude.

\section{REFERENCES}

[1] V. Sivasankar, S. Murugesh, S. Rajkumar and A. Darchen, "Cerium Dispersed in Carbon (CeDC) and Its Adsorption Behavior: A First Example of Tailored Adsorbent for Fluoride Removal from Drinking Water," Chemical Engineering Journal, Vol. 214, 2013, pp. 45-54. doi:10.1016/j.cej.2012.10.023

[2] WHO, "Guidelines for Drinking Water Quality," World Health Organization, Geneva, 2006.

[3] S. Ayoob and A. K. Gupta, "Fluoride in Drinking Water a Review on the Status and Stress Effects," Critical Reviews in environmental Science and Technology, Vol. 36, No. 6, 2006, pp. 433-487. doi:10.1080/10643380600678112

[4] M. H. Trivedi, R. J. Verma and N. J. Chinoy, "Effect of High Fluoride Water on Intelligence of School Children in India," Fluoride, Vol. 40, No. 3, 2007, pp. 178-183.

[5] A. J. Arulanantham, T. V. Ramakrishna and N. Balasubramanium, "Studies on Fluoride Removal by Coconut Shell Carbon," Indian Journal of Environmental Health, Vol. 13, No. 5, 1992, pp. 531-536.

[6] S. Kumar, A. Gupta and J. P. Yadav, "Fluoride Removal by Mixtures of Activated Carbon from Neem (Azadirachta) and Kikar (Acacia Arabica) Leaves," Indian Journal of Chemical Technology, Vol. 14, No. 4, 2007 , pp. 355-361.

[7] G. Alagumuthu, V. Veeraputhiran and R. Venkataraman, "Adsorption Isotherms on Fluoride Removal Batch Techniques," Archives of Applied Science Research, Vol. 2, No. 4, 2010, pp. 170-185.

[8] S. Chakrabarty and H. P. Sarma, "Defluoridation of Contaminated Drinking Water Using Neem Charcoal Adsorbent: Kinetics and Equilibrium Studies," International Journal of ChemTech Research, Vol. 4, 2012, pp. 511-516.

[9] C. Gisele, S. Bazanella, G. F. Silva, A. M. Vieira and R. Bergamasco, "Fluoride Removal from Water Using Combined Moringa oleifera/Ultrafiltration Process," Water, Air, and Soil Pollution, Vol. 223, No. 9, 2012, pp. 60836093.

[10] C. J. Atkinson, "The Flux and Distribution of Xylem Sap Calcium to Adaxial and Abaxial Epidermal Tissue in Relation to Stomatal Behavior," Journal of Experimental Botany, Vol. 42, 1991, pp. 987-993. doi:10.1093/jxb/42.8.987

[11] M. Mourabet, A. El. Rhilassi, H. El. Boujaady, M. Bennani-Ziatni, R. El. Hamri and A. Taitai, "Removal Offluoride from Aquous Solution by Adsorption on Apatitic Tricalcium Phosphate Using Bix-Behnken Design and Desirability Function," Applied Water Science, Vol. 258, 2012, pp. 4402-4410.

[12] Y. LiuZheng and A. Wang, "Response Surface Methodology for Optimizing Adsorption Process Parameters for Methylene Blue by a Hydrogel Composite," Adsorption
Science and Technology, Vol. 28, No. 10, 2010, pp. 913921. doi:10.1260/0263-6174.28.10.913

[13] V. Hernández-Montoyaa, L. A. Ramírez-Montoya, A. Bonilla-Petriciolet and M. A. Montes-Moránb, "Optimizing the Removal of Fluoride from Water Using New Carbons Obtained by Modification of Nut Shell with a Calcium Solution from Egg Shell," Biochemical Engineering Journal, Vol. 62, 2012, pp. 1-7. doi:10.1016/j.bej.2011.12.011

[14] M. K. Mondal, "Removal of Pb (II) from Aqueous Solution by Adsorption Using Activated Tea Waste," Korean Journal of Chemical Engineering, Vol. 27, No. 1, 2010, pp. 144-151. doi:10.1007/s11814-009-0304-6

[15] A. K. Yadav, R. Abbassi and A. Gupta and M. Dadashzadeh, "Removal of Fluoride from Aquous Solution and Groundwater by Wheat Straw, Saw Dust and Activated Carbon of Sugarcane," Ecological Engineering, Vol. 52, 2013, pp. 211-218. doi:10.1016/j.ecoleng.2012.12.069

[16] O. Genc, Y. Yalcinkaya, E. Buyuktuncel, A. Denilzili, M. Y. Arica and S. Bektas, "Uranium Recovery by Immobilized and Dried Powdered Biomass, Characterization and Comparison," International J of Minerology Process, Vol. 68, 2003, pp. 93-107. doi:10.1016/S0301-7516(02)00062-5

[17] S. V. Mohan and J. Karthikeyan, "Removal of Lignin and Tannin Aquous Solution by Adsorption onto Activated Charcoal," Environmental Pollution, Vol. 97, 1997, pp. 183-197. doi:10.1016/S0269-7491(97)00025-0

[18] T. Ilhami, B. Gulay, Y. Emine and B. Gokben, "Equilibrium and Kinetic Studies on Biosorption of $\mathrm{Hg}(\mathrm{II}), \mathrm{Cd}(\mathrm{II})$ and $\mathrm{Pb}(\mathrm{II})$ Ions onto Micro Algae Chlamydomonasreinhardtii," Journal of Environmental Management, Vol. 77, No. 2, 2005, pp. 85-92. doi:10.1016/j.jenvman.2005.01.028

[19] S. Panumati, K. Chudecha, P. Vankhaew, V. Choolert, L. Chuenchom, W. Innajitara and O. Sirichote, "Adsorption of Phenol from Diluted Aqueous Solutions by Activated Carbons Obtained from Bagasse, Oil Palm Shell and Pericarp of Rubber Fruit," Songklanakarin Journal of Science \& Technology, Vol. 30, No. 2, 2008, pp. 185-189.

[20] M. Murugan and E. Subremanian, "Studies on Defluoridation of Water by Tamarindseed, an Unconventional Biosorbent," Journal of Water and Health, Vol. 4, No. 4, 2006, pp. 453-461.

[21] R. Bhaumik, N. K. Mondal, B. Das, P. Roy, K. C. Pal, C. Das, A. Banerjee and J. K. datta, "Eggshell Powder as an Adsorbent for Removal of Fluoride from Aquoussolution : Equilibrium, Kinetic and Thermodynamic Studies," EJournal of Chemistry, Vol. 9, 2012, pp. 1457-1480. doi: $10.1155 / 2012 / 790401$

[22] D. J. Killedar and D. S. Bhargava, "Effects of Stirring Rate Temperature on Luoride Removal by Fishbone Charcoal," International Journal of Occupational and Environmental Health, Vol. 35, No. 2, pp. 1993, pp. 8187.

[23] S. V. Ramanaiah, S. V. Mohan, B. Rajkumar and P. N. Sarma, "Monitoring of Fluoride Concentration in Ground Water of Prakasham District in India: Correlation with Physic-Chemocal Parameters," Journal of Environmental 
Science and Engineering, Vol. 48, 2006, pp. 129-134.

[24] A. R. Tembhurkar and S. Dongre, "Studies on Fluoride Removal Using Adsorptionprocess," Journal of Envi- ronmental Health Science and Engineering, Vol. 48, No. 3, 2006, pp. 151-156. 